\title{
Studi Suhu Pengovenan terhadap Umur Simpan Telur Asin
}

\author{
Study on the Oven Temperature to Shelf Life of Salted Eggs
}

\author{
D. Novia, S. Melia, dan N.Z. Ayuza
}

Fakultas Peternakan Universitas Andalas

Kampus Unand Limau Manis Padang, 25163

e-mail: deni_novia@yahoo.co.id

(Diterima: 11 Agustus 2011; Disetujui: 2 Desember 2011)

\begin{abstract}
This study aims to determine the effect of oven temperature on the moisture content, total bacterial colonies and shelf life of salted eggs. This study uses duck eggs coast (Indian Runner) maximum 48-hourold fresh as many as 200 eggs weighing 65-70 grams obtained from a breeder in Anduring Padang. The research used the experimental method with randomized block design (RBD), consists of 4 treatments and 5 groups as replication. Treatment $A$ (oven temperature $\left.70^{\circ} \mathrm{C}\right), B\left(80^{\circ} \mathrm{C}\right), \mathrm{C}\left(90^{\circ} \mathrm{C}\right)$ and $\mathrm{D}\left(100^{\circ} \mathrm{C}\right)$. Eggs were roasted in the oven for 6 hours after that eggs were stored for 25 days. Variables measured were moisture content, total bacterial colonies, and shelf life of salted eggs. The results showed significantly different effects $(P<0.05)$ on moisture content and shelf life but showed non significant effects $(P>0.05)$ on total bacterial colonies of salted eggs. Based on the results of this study, it can be concluded that the oven temperature of salted egg is best at $100^{\circ} \mathrm{C}$ with moisture content of $48.79 \%$, total bacterial colonies $7.35 x$ $10^{4} \mathrm{CFU} / \mathrm{g}$, and 38.80 days shelf life.
\end{abstract}

Keywords: salted egg, oven temperature, moisture content, total bacterial colonies, shelf life

\section{PENDAHULUAN}

Telur sangat penting dalam pemenuhan kebutuhan gizi masyarakat. Telur merupakan bahan pangan yang cukup sempurna yang sangat akrab dengan kehidupan sehari-hari, dimana telur mengandung zat gizi yang tinggi yang mudah dicerna, kaya protein, lemak dan zat-zat lain yang dibutuhkan tubuh. Telur memiliki sifat yang mudah rusak terutama disebabkan oleh kandungan protein di dalamnya sehingga merupakan media yang cocok untuk pertumbuhan mikroorganisme. Hal inilah yang menyebabkan perlunya pengawetan dilakukan serta penanganan sehingga dapat memperpanjang umur simpan dengan kualitas yang lebih baik.

Pengolahan telur ayam lebih luas dari telur itik, pada umumnya telur itik diolah menjadi telur asin. Metode pengasinan dapat mengawetkan telur itik, mengurangi bau amis dan menciptakan rasa khas. Proses pengasinan dilakukan dengan menggunakan garam sebagai bahan pengawetnya, namun memiliki masa simpan yang tidak terlalu lama.
Seiring dengan perkembangan teknologi dan semakin disukainya telur asin oleh masyarakat, pemasarannyapun semakin luas. Teknologi pemasakan telur asin sudah mulai bervariasi selain untuk menciptakan rasa khas juga untuk memperpanjang masa simpan dari telur asin. Pemasakan telur asin menggunakan oven dengan memanfaatkan sumber panasnya dapat memperpanjang umur simpan serta mempertahankan kualitas telur asin. Menurut Mulyadi (2010) telur asin yang dapat lebih panjang umur simpannya hingga 3-4 minggu dan nilai gizi dapat lebih dipertahankan dengan perebusan selama 6 jam dan di oven 2 jam dibandingkan telur asin biasa hanya tahan 1 minggu dengan perebusan selama 15 menit. Berdasarkan hasil pra penelitian pemasakan telur asin dengan menggunakan oven suhu $70^{\circ} \mathrm{C}$ selama 6 jam dapat dipertahankan umur simpan lebih lama hingga 25 hari dibandingkan telur asin yang direbus selama 15 menit hanya bisa dipertahankan selama 7 hari. Penelitian ini bertujuan untuk mengetahui apakah ada pengaruh suhu pengovenan 
terhadap kadar air, total koloni bakteri dan umur simpan telur asin.

\section{METODE}

\section{Materi Penelitian}

Penelitian ini menggunakan telur itik Pesisir (Indian Runner) segar umur maksimal 24 jam yang beratnya 65-70 g sebanyak 200 butir yang didapatkan dari peternak itik di Anduring Padang. Kemudian untuk adonan telur asin digunakan bubuk batu bata, abu gosok dan garam dengan perbandingan $3: 2$ : 1, (3 000 gram : 2000 gram : 1000 gram) dan air sebanyak $3500 \mathrm{ml}$. Adapun bahan untuk analisis terdiri dari aquades, bubuk PCA (Plate Count Agar), pepton dan alkohol.

Alat-alat yang digunakan dalam penelitian ini, antara lain : wadah, oven listrik (oxone), alat peniris, labu ukur $500 \mathrm{ml}$, bupet mikro, timbangan analitik, bunsen, gelas ukur, tabung reaksi, saringan, kapas, cawan porselen, desikator, neraca analitik, beaker glass, tissue, petridish, tabung Erlemenyer, magnetic stirer, lumpang dan mortal, inkubator, autoclave, lamina air flow, hocky stick, spatula, beaker plastik dan Quebec Colony Counter.

\section{Metoda Penelitian}

Penelitian menggunakan metoda eksperimen dengan Rancangan Acak Kelompok (RAK) dengan 4 perlakuan dan 5 kelompok sebagai ulangan. Sebagai perlakuan adalah suhu pengovenan telur asin sebagai berikut : perlakuan A (suhu $70^{\circ} \mathrm{C}$ ), perlakuan B (suhu $80^{\circ} \mathrm{C}$ ), perlakuan $\mathrm{C}$ (suhu $90^{\circ} \mathrm{C}$ ) dan perlakuan $\mathrm{D}$ (suhu $100^{\circ} \mathrm{C}$ ).

Model matematika yang digunakan dalam percobaan ini adalah :

Keterangan :

$$
Y i j=\mu+\alpha i+\beta j+\sum i j
$$

Yij : Hasil pengamatan dari unit percobaan yang mendapat perlakuan ke-i, kelompok ke-j.

$\mu \quad$ : Nilai tengah umum.

$\alpha i \quad$ : Pengaruh perlakuan ke-i

$\beta j \quad$ : Pengaruh kelompok ke-j $\sum \mathrm{ij} \quad$ : Pengaruh sisa dari unit percobaan yang mendapat perlakuan ke-i dan kelompok ke-j.

i : Perlakuan (A, B, C dan D)

j : Banyak kelompok (1,2,3,4 dan 5)

Jika antar perlakuan berbeda nyata $(\mathrm{P}<0.05)$ dan berebeda sangat nyata $(\mathrm{P}<0.01)$ maka dilakukan uji lanjut dengan Duncan's Multiple Range Test (DMRT).

Peubah yang diamati adalah kadar air menggunakan metode oven, total koloni bakteri menggunakan metode Standard Plate Count dan umur simpan. Penentuan umur simpan dengan organoleptik mengunakan parameter sensori (warna, flavour, aroma, rasa dan tekstur) terhadap sampel yang mengindikasikan tingkat kesegaran produk. Untuk telur asin oven dilihat perubahan yang terjadi pada telur setelah 25 hari, kemudian diamati dengan interval selama 3 hari sampai rusak secara fisik dan fisual. Analisis pendugaan umur simpan sesuai batas akhir penurunan mutu yang dapat ditaksir yaitu timbulnya perubahan aroma, tekstur dan warna. Perubahan aroma menjadi tidak sedap, tekstur menjadi lembek dan perubahan warna menandakan bahwa telur asin telah rusak. Prosedur kerja dilakukan berdasarkan modifikasi Warisno (2005), untuk satu kelompok, yaitu :

1. Telur itik umur maksimal 24 jam sebanyak 40 butir dibersihkan.

2. Kemudian disiapkan medium pengasinan diantaranya bubuk bata, abu gosok, garam dapur dengan perbandingan $3: 2: 1$ (600 gram : 400 gram : 200 gram), dan $500 \mathrm{ml}$ air.

3. Telur itik dibalur dengan medium pengasinan dengan ketebalan $0.5 \mathrm{~cm}$.

4. Setelah itu dilakukan pemeraman selama 6 hari diruang yang terbuka.

5. Setelah pemeraman 6 hari lalu telur tersebut dicuci dengan menggunakan air dan langsung ditiriskan

6. Telur asin yang telah dibersihkan dilakukan pengacakan untuk memberikan perlakuan suhu pengovenan masing-masing yaitu perlakuan A (suhu $70^{\circ} \mathrm{C}$ ), perlakuan $\mathrm{B}\left(\right.$ suhu $80^{\circ} \mathrm{C}$ ), 
perlakuan $\mathrm{C} \quad\left(\right.$ suhu $\left.90^{\circ} \mathrm{C}\right)$ dan perlakuan D (suhu $100^{\circ} \mathrm{C}$ ).

7. Kemudian dilakukan pengovenan selama 6 jam masing-masing perlakuan dan dianalisis 0 hari sebagai pembanding.

8. Analisis telur asin dilakukan setelah penyimpanan selama 25 hari terhadap

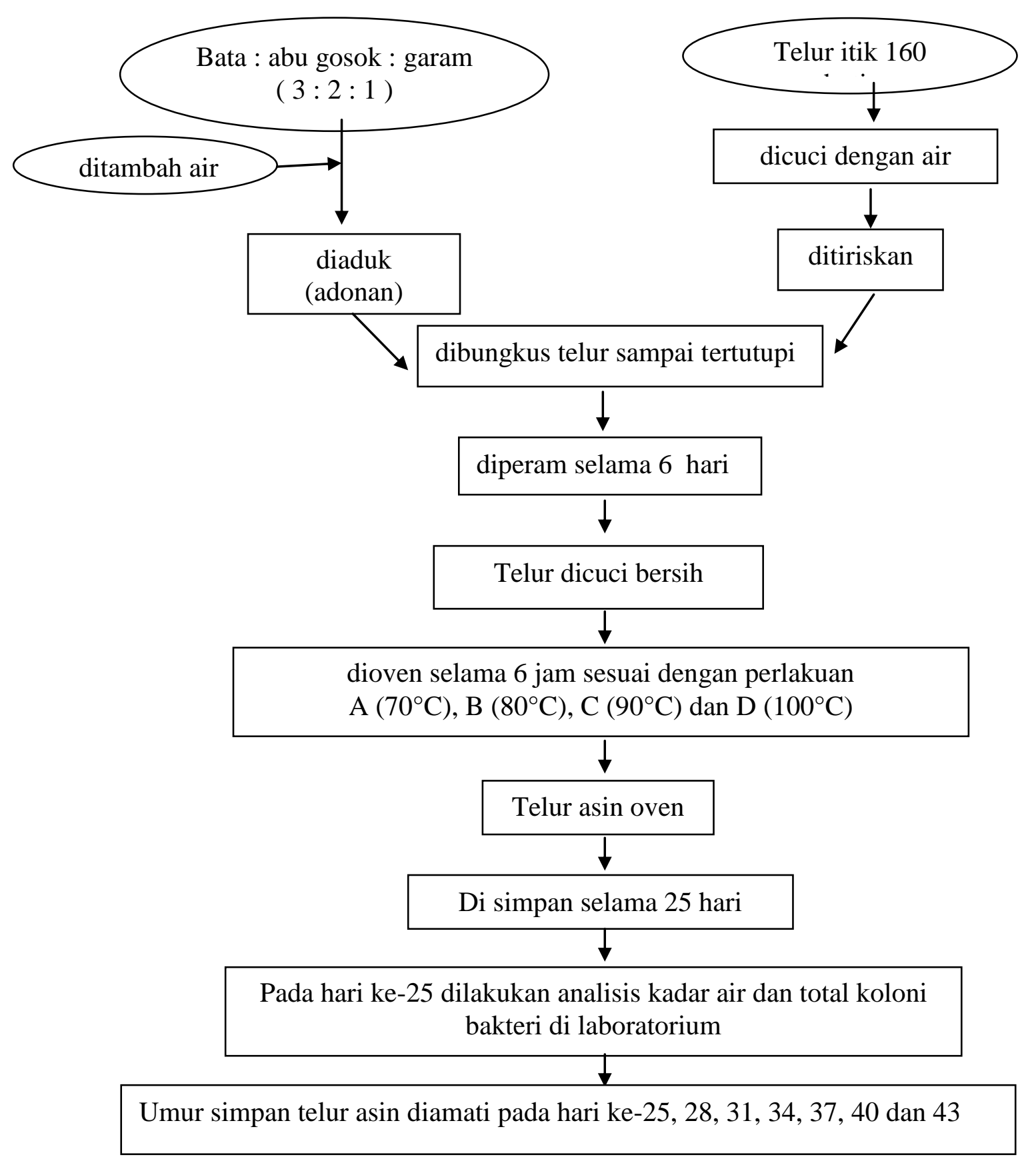

Gambar 1. Diagram alir pembuatan telur asin oven kadar air, total koloni bakteri dan umur simpan setiap 3 hari (pada umur telur asin hari ke-25, ke-28, ke-31, ke-34, ke-37, ke-40 dan hari ke-43).

Penelitian ini dilaksanakan di Laboratorium Teknologi Hasil Ternak Fakultas Peternakan Universitas Andalas Padang. 
Tabel 1. Nilai rataan kadar air telur asin oven hasil penelitian

\begin{tabular}{ccc}
\hline Perlakuan & 0 hari $(\%)$ & 25 hari $(\%)$ \\
\hline A & 64,73 & $59,00^{\mathrm{a}}$ \\
B & 61,68 & $55,22^{\mathrm{b}}$ \\
C & 56,68 & $54,77^{\mathrm{b}}$ \\
D & 53,97 & $48,79^{\mathrm{c}}$ \\
\hline KK $(\%)$ & & 4,08 \\
\hline
\end{tabular}

Keterangan : Rataan dengan superskrip huruf yang berbeda menunjukkan pengaruh yang berbeda nyata $(\mathrm{P}<0,05)$, $\mathrm{A}=$ suhu pengovenan $70^{\circ} \mathrm{C}, \mathrm{B}=80^{\circ} \mathrm{C}, \mathrm{C}=90^{\circ} \mathrm{C}$ dan $\mathrm{D}=100^{\circ} \mathrm{C}$

Tabel 2. Nilai rataan total koloni bakteri dan umur simpan telur asin oven hasil penelitian

\begin{tabular}{cccc}
\hline Perlakuan & $\begin{array}{c}\text { Total Koloni Bakteri } \\
\left.\left(1 \times 10^{4}\right) \text { CFU/g }\right) \\
(0 \text { hari })\end{array}$ & $\begin{array}{c}\text { Total Koloni Bakteri } \\
\left.\left(1 \times 10^{4}\right) \text { CFU/g }\right) \\
(25 \text { hari })\end{array}$ & $\begin{array}{c}\text { Umur simpan } \\
(\text { hari })\end{array}$ \\
\hline A & 10,46 & 11,66 & $27,40^{\mathrm{b}}$ \\
B & 8,55 & 10,99 & $29,80^{\mathrm{b}}$ \\
C & 6,29 & 9,22 & $36,20^{\mathrm{a}}$ \\
D & 1,98 & 7,35 & $38,80^{\mathrm{a}}$ \\
KK $(\%)$ & & 2,44 & 7,20 \\
\hline
\end{tabular}

Keterangan : Rataan dengan superskrip huruf yang berbeda menunjukkan pengaruh yang berbeda nyata $(\mathrm{P}<0,05)$, $\mathrm{A}=$ suhu pengovenan $70^{\circ} \mathrm{C}, \mathrm{B}=80^{\circ} \mathrm{C}, \mathrm{C}=90^{\circ} \mathrm{C}$ dan $\mathrm{D}=100^{\circ} \mathrm{C}$

\section{HASIL DAN PEMBAHASAN}

Nilai kadar air dapat dilihat pada Tabel 1 , total koloni bakteri dan umur simpan telur asin oven dengan level suhu yang berbeda berdasarkan penelitian yang telah dilakukan dapat dilihat pada Tabel 2.

\section{Kadar Air}

Berdasarkan Tabel 1 kadar air telur asin oven umur 0 hari yang didapatkan adalah 53,97-64,73\%. Seiring dengan semakin tinggi suhu pengovenain maka terjadi penurunan kadar air dan total koloni bakteri. Kadar air telur asin oven pada 0 hari terendah terdapat pada pelakuan $\mathrm{D}$ dengan suhu pengovenan $100^{\circ} \mathrm{C}$ yaitu $53,97 \%$, diikuti perlakuan $\mathrm{C}$ suhu $90^{\circ} \mathrm{C}$ yaitu $56,68 \%$, perlakuan $\mathrm{B}$ suhu $80^{\circ} \mathrm{C}$ yaitu $61,68 \%$ dan kadar air tertinggi terdapat pada perlakuan A suhu $70^{\circ} \mathrm{C}$ yaitu $64,73 \%$.

Selama penyimpanan terjadi penurunan kadar air. Menurunnya kadar air telur asin oven disebabkan karena terjadinya penguapan selama penyimpanan menyebabkan kadar protein akan meningkat dan mempengaruhi aktivitas mikroorganisme.

Nilai rataan kadar air telur asin oven dengan level suhu yang berbeda setelah disimpan selama 25 hari berdasarkan penelitian yang telah dilakukan dapat dilihat pada Tabel 1. Berdasarka Tabel 1 dapat dilihat bahwa semakin tinggi suhu pengovenan maka kadar air telur asin oven semakin menurun. Hal ini disebabkan karena pengaruh suhu, dimana suhu pengovenan berpengaruh terhadap kadar air telur asin oven. Selain itu disebabkan karena selama pengovenan menyebabkan menguapnya air dan zat-zat yang larut dalam air. Maruddin (2004) bahwa kadar air daging sapi asap menurun seiring dengan lamanya periode pengasapan.

Hasil analisis keragaman menunjukkan bahwa suhu pengovenan memberikan pengaruh terhadap kadar air telur asin. Hasil uji lanjut Duncan menunjukkan bahwa kadar air masing-masing perlakuan menunjukkan pengaruh berbeda nyata. Sedangkan perlakuan B tidak berpengaruh terhadap perlakuan $\mathrm{C}$ suhu $90^{\circ} \mathrm{C}$. 
Rataan kadar air telur asin oven yang telah disimpan selama 25 hari terendah terdapat pada perlakuan $\mathrm{D}$ dengan suhu pengovenan $100^{\circ} \mathrm{C}$ dengan rataan $48,79 \%$ dan kadar air tertinggi terdapat pada perlakuan A suhu $70^{\circ} \mathrm{C}$ dengan rataan $59,00 \%$. Rendahnya kadar air pada perlakuan D dengan suhu pengovenan $100^{\circ} \mathrm{C}$ yaitu dengan rataan $48,79 \%$ disebabkan karena pengaruh pemanasan dengan suhu yang tinggi. Dimana suhu berpengaruh terhadap kadar air telur asin. Hal ini disebabkan karena selama proses pengovenan menyebabkan menguapnya air dan zat yang larut dalam air.

Perlakuan A dengan suhu pengovenan $70^{\circ} \mathrm{C}$ memiliki kadar air tertinggi yaitu dengan rataan $59,00 \%$. Tingginya kadar air pada perlakuan A disebabkan karena pengaruh suhu pengovenan yang rendah. Dimana semakin rendah suhu pengovenan kadar air telur asin semakin meningkat dan sebaliknya semakin tingginya suhu pengovenan kadar air semakin menurun. Sesuai dengan hasil penelitian Saputra dan Ningrum (2010) suhu berpengaruh terhadap laju pengeringan, suhu $120^{\circ} \mathrm{C}$ laju pengeringannya lebih besar dibanding suhu $80^{\circ} \mathrm{C}$ dan suhu $80^{\circ} \mathrm{C}$ laju pengeringannya lebih besar dari suhu $65^{\circ} \mathrm{C}$.

Berbeda tidak nyatanya perlakuan B dengan suhu $80^{\circ} \mathrm{C}$ dan perlakuan $\mathrm{C}$ suhu $90^{\circ} \mathrm{C}$ disebabkan karena pada kisaran suhu pemanasan $80-90^{\circ} \mathrm{C}$ tidak mempengaruhi penurunan kadar air. Selain itu disebabkan karena pada suhu tersebut telah terjadi koagulasi (penggumpalan) sehingga tidak mempengaruhi kadar air telur asin. Sejalan dengan pendapat Novia, Melia dan Ayuza (2011) kadar protein telur asin oven pada suhu $80^{\circ} \mathrm{C}$ dan $90^{\circ} \mathrm{C}$ juga tidak berpengaruh.

\section{Total Koloni Bakteri}

Total koloni bakteri pada 0 hari (Tabel2) terendah terdapat pada perlakuan $\mathrm{D}$ dengan suhu pengovenan $100^{\circ} \mathrm{C}$ yaitu $1,98 \times 10^{4}$ $\mathrm{CFU} / \mathrm{g}$, diikuti perlakuan $\mathrm{C}$ suhu $90^{\circ} \mathrm{C}$ yaitu $6,29 \times 10^{4} \mathrm{CFU} / \mathrm{g}$, perlakuan B suhu $80^{\circ} \mathrm{C}$ yaitu $8,55 \times 10^{4} \mathrm{CFU} / \mathrm{g}$ dan total koloni tertinggi terdapat pada perlakuan $\mathrm{A}$ suhu $70^{\circ} \mathrm{C}$ yaitu $10,46 \times 10^{4} \mathrm{CFU} / \mathrm{g}$. Dapat dilihat bahwa semakin tinggi suhu pengovenan total koloni bakteri semakin rendah. Hal ini disebabkan karena selama poses pengovenan akan menurunkan kadar air telur asin sehingga ketersedian air untuk kebutuhan mikroba juga berkurang.

Berdasarkan Tabel 2 dapat dilihat bahwa rataan total koloni bakteri 0 hari dengan 25 hari tidak jauh berbeda, artinya tidak ada pertumbuhan bakteri yang signifikan selama penyimpanan. Rataan total koloni bakteri yang terdapat pada telur asin oven dengan level suhu $70^{\circ} \mathrm{C}$ sampai $100^{\circ} \mathrm{C}$ berkisar antara $7,35 \mathrm{x} 10^{4} \mathrm{CFU} / \mathrm{g}$ sampai $11,66 \times 10^{4} \mathrm{CFU} / \mathrm{g}$. Hasil analisis keragaman telur asin oven tidak mempengaruhi total koloni bakteri. Hal ini menandakan bahwa tidak adanya pengaruh suhu pengovenan telur asin terhadap total koloni bakteri. Dimana total koloni bakteri yang terdapat pada telur asin oven masih aman untuk di konsumsi. Menurut Wulandari (1999) bahwa produk telur asin dengan total koloni bakteri dibawah $10^{6} \mathrm{CFU} / \mathrm{g}$ masih aman untuk dikonsumsi.

Bakteri yang terdapat pada telur asin oven telah mati pada proses pengovenan. Selain itu, proses pemanasan berpengaruh terhadap protein keratin yang berbentuk serat yang terdapat pada kulit telur. Selama proses pemanasan protein keratin akan terkoagulasi sehingga ikatan antar serat semakin kuat menutupi pori-pori telur sehingga menyebabkan mikroorganisme tidak dapat masuk. Sesuai dengan pendapat Novia et al. (2011) koagulasi terjadi karena pengaruh suhu.

\section{Umur Simpan}

Berdasarkan Tabel 2 dapat dilihat bahwa rataan umur simpan telur asin tertinggi terdapat pada perlakuan $\mathrm{D}$ dengan suhu pengovenan $100^{\circ} \mathrm{C}$ dengan rataan 38,80 hari, diikuti oleh perlakuan $\mathrm{C}$ suhu $90^{\circ} \mathrm{C}$ dengan rataan 36,20 hari, perlakuan $\mathrm{B}$ suhu $80^{\circ} \mathrm{C}$ dengan rataan 29,80 hari dan rataan umur simpan terendah terdapat pada perlakuan A suhu $70^{\circ} \mathrm{C}$ yaitu 27,40 hari. 
Hasil analisis keragaman menunjukkan bahwa perlakuan suhu pengovenan yang berbeda berpengaruh terhadap umur simpan telur asin oven. Hasil uji lanjut Duncan menunjukkan bahwa umur simpan telur asin perlakuan D berbeda dengan perlakuan A dan perlakuan $\mathrm{B}$, namun tidak berbeda dengan perlakuan $\mathrm{C}$.

Lebih lamanya umur simpan perlakuan D disebabkan karena kadar air telur asin yang telah menurun sehingga umur simpan telur lebih lama yaitu 38,8 hari yang dilihat dari perubahan warna menjadi tidak enak dan tekstur menjadi lebih lembek. Selain kadar air yang rendah, penyebab lebih lamanya umur simpan pada perlakuan D juga disebabkan oleh pengaruh pemanasan terhadap kulit telur, dimana pada kulit telur terdapat protein keratin yang berbentuk serat. Pemanasan protein keratin yang berbentuk serat akan menyebabkan ikatan antar serat semakin kuat menutupi pori-pori telur akan memadat dan menutupi pori-pori telur, sehingga mikroorganisme yang dapat merusak telur tidak dapat masuk menyebabkan umur simpan telur lebih lama. Ditambahkan Muchtadi (2009) bahwa pori-pori kulit telur ditutupi oleh lapisan protein karatin

Sedangkan pada perlakuan A dengan suhu pengovenan $70^{\circ} \mathrm{C}$ sudah mengalami perubahan pada lama penyimpanan 27 hari yang ditandai dengan perubahan tekstur menjadi lembek dan aroma yang tidak enak. Sedangkan pada perlakuan B dan C terjadi perubahan pada hari ke-29 dan hari ke-36. Dimana, semakin tinggi suhu pengovenan masa simpan telur asin akan semakin lama. Hasil penelitian Novia, Melia (2010) peningkatan lama pengasapan akan meningkatkan masa simpan telur asin asap. Hasil penelitian Torrico et al. (2010) dan (2011) telur yang dilapisi emulsi dapat mengawetkan kualitas internal dan memperpanjang masa simpan telur. Ditambahkan juga oleh Novia, Juliyarsi dan Putra (2010) Perendaman telur dalam air sisa penirisan getah gambir dapat memperpanjang masa simpan telur sampai 1 bulan. Sejalan dengan itu hasil penelitian Maryati, Jusmawati dan Karmila (2008) pengawetan telur ayam ras memanfaatkan daun jambu biji memperpanjang masa simpan telur sampai 1 bulan.

\section{KESIMPULAN}

Dari hasil penelitian yang telah dilakukan dapat disimpulkan bahwa dengan semakin meningkatnya suhu pengovenan akan menurunkan kadar air, total koloni dan meningkatkan umur simpan. Suhu pengovenan telur asin yang paling baik adalah suhu $100^{\circ} \mathrm{C}$ dengan kadar air $48,79 \%$, total koloni bakteri $7,35 \times 10^{4} \mathrm{CFU} / \mathrm{g}$, dan umur simpan 38,80 hari.

\section{DAFTAR PUSTAKA}

Maruddin, F. 2004. Kualitas Daging Sapi Asap pada Lama Pengasapan dan Penyimpanan. J. Sains \& Teknologi. ISSN 1411-4674. Agustus 2004. Vol.4 No.2. Hal 83-90.

Maryati, Jusmawati dan M. Karmila. 2008. Pemanfaatan Daun Jambu Biji (Psidium guajava L) sebagai Alternatif Pengawetan Telur Ayam Ras. Jurnal Nalar volume 1 Nomor 7. Hal 320.

Muchtadi, D. 2009. Prinsip Teknologi Pangan Sumber Protein. Penerbit Alfabeta, Bandung.

Mulyadi. 2010. Telur asin bakar. http://www.google.com. Diakses pada 04/02/2010, pukul $7.45 \mathrm{pm}$.

Novia, D., I. Juliarsi dan A.A. Putra. 2010. Pengawetan telur dengan menggunakan air sisa penirisan getah gambir di peternakan agung abadi Kec. Harau Bab. 50 Kota. Warta Pengabdian Andalas. Volume XVI Nomor 25 Edisi Desember 2010. Hal : 109-121.

Novia, D. dan S. Melia. 2010. The effect time of smoking process and storage of smoking salting egg with material coco fiber for water, $\mathrm{pH}$, bacterial colony forming and formaldehyde. Proceeding : International Seminar on Food and 
Agricultural Sciences 2010. AgriTech

Press. ISBN 978-602-96301-0-7. Bukittinggi-Indonesia. Hal : 243-246.

Novia, D., S. Melia dan N.Z. Ayuza. 2011. Kajian Suhu Pengovenan terhadap Kadar Protein dan Nilai Organoleptik Telur Asin. Jurnal Peternakan. Volume 8 Nomor 2 September 2011. Hal : 7076.

Saputra, A. dan D.K. Ningrum. 2010. Pengeringan Kunyit Menggunakan Microwave dan Oven. Artikel Universitas Diponegoro. Semarang.

Torrico, D.D., W. Jirangrat, H. Kyoon No, W. Prinyawiwatkul, B. Ge dan D.Ingram. 2010. A. Novel Emulsion Coating and Its Effects on Internal Quality and Shelf
Life of Eggs During Room Temperature Storage. International Journal of Food Science \& Technology. Volume 45. Issue 11. November 2010. Hal : 22412249.

Torrico, D.D., H. Kyoon No, W. Prinya wiwatkul, M. Janes, J.A.H. Corredor dan L.F. Osorio. 2011. A. Mineral OiChitosan Emulsion Coating Affect Quality and Shelf Life of Coated Eggs during Refrigerator and Room Temperature Storage. International Journal of Food Science \& Technology. Volume 76. Issue 4. May 2011. Hal : S262-S268.

Warisno. 2005. Membuat Telur Asin Aneka Rasa. Agro Media Pustaka, Jakarta. 